\title{
Література:
}

1. Господарський процесуальний кодекс України. Редакція від 28.08.2018 p., підстава - 2475-VIII. URL: https://zakon.rada.gov.ua/ laws/show/1798-12 (дата звернення 10.05.2021)

2. Господарський процесуальний кодекс України. Редакція ГПК від 03.08.2017 p. URL: https://zakon.rada.gov.ua/laws/show/1798-12 (дата звернення 10.05.2021)

3. Згама А.О. Щодо оптимізації процесуальних форм у господарському процесі: наказне провадження та спрощене позовне провадження. 25 років господарській юрисдикиії в Украӥні: досвід та перспективи : матеріали Всеукр. наук.- практ. конф. (м. Харків, 20 трав. 2016 р.). Харків : Право, 2016. С. 52-56.

4. Медведева Е.В. Тенденции дифференциации и унификации в упрощенных производствах цивилистического процесса. Вестник Омского университета. Серия «Право». 2018. № 2 (55). С. 140-145.

5. Суярко Т.Д. Спрощені провадження господарського судочинства як механізм забезпечення доступності правосуддя у господарських справах. 25 років господарській юрисдикиї в Україні: досвід та перспективи : матеріали Всеукр. наук.-практ. конф. (м. Харків, 20 трав. 2016 р.). Харків: Право, 2016. С. 155-158.

\section{DOI https://doi.org/10.30525/978-9934-26-116-9-18}

\section{РОЛЬ ДЕРЖАВИ ТА БІЗНЕСУ У ФОРМУВАННІ ПРАВОВОЇ МОДЕЛІ СТАЛОГО РОЗВИТКУ УКРАЇНИ}

\section{Мішенко В. С.}

кандидат юридичних наук, науковий співробітник відділу проблем модернізаиії господарського права та законодавства ДУ «Інститут економіко-правових досліджень імені В. К. Мамутова Національної академії наук України» м. Київ, Україна

За останні роки в Україні назріла необхідність вирішення нових актуальних завдань, що вимагає пошуку вдосконалених підходів, здатних забезпечити безперервне економічне зростання в нових умовах функціонування. Це вбачається можливим за умови переходу на модель сталого розвитку, формування якої здійснювалося внаслідок 
поступового усвідомлення суспільством природоохоронних, економічних і соціальних проблем, які впливають на стан природного середовища. Наразі саме концепція сталого розвитку вважається найперспективнішою ідеологією XXI століття, яка, 3 поглибленням наукової обгрунтованості, витіснить усі наявні світоглядні ідеології, як такі, що є фрагментарними та неспроможними забезпечити збалансований розвиток цивілізації.

На основі тріади економічних, соціальних та екологічних складових розробляються національні стратегії сталого розвитку або переходу до нього. Більшістю вчених сталий розвиток розглядається як сума трьох складових - екологічного, економічного та соціального розвитку. Найбільшою мірою триєдина проблематика сталого розвитку стосується господарсько-правових засобів. Саме вони мають своїм завданням забезпечення цілісності правової регламентації найважливіших видів економічної діяльності, пов'язаних із господарським використанням природних ресурсів та забезпеченням соціальної спрямованості природокористування [1, с. 25].

Cталість - це здатність системи виживати нескінченно, не використовуючи більше ресурсів, ніж вона може відновити, та не зловживаючи ними. А отже, більш сталою вбачається саме економіка, у якій існує менший розрив між використанням/зловживанням ресурсами та здатністю Землі відновлювати їх. Деякі технології, спрямовані на захист довкілля, хоча й запроваджені $з$ добрими намірами, не допомагають зменшити цей розрив [2].

Останнім часом ідею сталого розвитку часто почали плутати зі зменшенням рівня забруднення, екологічно чистим способом життя або навіть просто зі свідомим ставленням до проблем про довкілля. Це дозволило багатьом організаціям по всьому світу, особливо бізнесу, вдавати, що їхні дії сприяють сталому розвитку та спрямовані на боротьбу із глобальною проблемою. Не можна ототожнювати поняття «інформованість про екологічні проблеми» та «сприяння сталому розвитку»: «захист довкілля» полягає у зменшенні впливу на навколишнє середовище через економічну активність та іншу діяльність людини, як-от правильне поводження з відходами. Зараз хтось може сказати, що дії, спрямовані на зменшення впливу на довкілля через економічну діяльність, це питання «пристойності», яке не повинно вимагати почесної відзнаки. Сталий розвиток - це дещо більше, ніж зменшення шкоди. Він пов'язаний 3 управлінням спільними та суспільними ресурсами, щоб переконатися, що їх не використовують надмірно або зловживають ними, аби всі люди мали справедливий та однаковий доступ до них [2]. 
Наразі бізнес, у тому числі в Україні, бере активну участь у впровадженні концепції сталого розвитку [3]. Проте, більшість стратегій з КСВ - це просто PR-кампанії. Насправді, вони відображають як недостатне розуміння цих проблем з боку компаній, так і вкрай низьку пріоритетність цієї проблематики в основній діяльності компаній. Компанії просто не спроможні вирішити подібні питання з огляду на їхні бізнес-моделі, вони нездатні брати на себе таку відповідальність.

Наразі більшість підприємств орієнтовані на досягнення фінансових результатів, а не на соціальну перспективу, це цілком зрозуміло, оскільки саме фінансова доцільність діяльності підприємств визначає можливості їх існування та функціонування. Систему соціальної спрямованості вітчизняні підприємства тривалий час сприймають лише як джерело необгрунтованих додаткових витрат. Проте, сучасний стан популяризації корпоративно-соціальної відповідальності все ж таки тісно пов'язаний із економічними перевагами, які досягаються завдяки побудові соціально-відповідальної ділової репутації. Така активність 3 боку бізнесу не є результатом імперативних норм або заходів стимулюючого характеру, іï природа зовсім інша, вона $є$ добровільною ініціативою робити більше, ніж зобов'язаний за законом. Проте, встановлено, ще за сочіально-відповідальними та екологічними ініціативами з боку бізнесу не завжди стоять ідеї суспільного блага, часто мають місие неетичні маркетингові технологіï.

При цьому, увага суспільства часто зосереджується саме на бізнесі, оскільки існує припущення, що на нього простіше впливати, ніж на державу. У такий спосіб люди виступають за ініціативи з КСВ, оскільки вони більше не розраховують на те, що держава виконає свої соціальні обов'язки. Або, в деяких випадках, вони звертаються до підприємств з приводу гарантування соціальних цінностей, тому що вони стурбовані тим, що держави занадто небезпечні чи корумповані. Проте такий підхід $\epsilon$ оманливим, а КСВ не може замінити державні стратегії, тому не варто перекладати відповідальність 3 держави на бізнес, бо це відповідальність держави - захищати суспільне благо та сприяти сталому розвитку.

Зі свого боку, бізнес має можливості допомогти державі у переході до сталого розвитку. Підприємства можуть стати надійними партнерами для визначення конкретних дій громади на шляху до розвитку, особливо, якщо йдеться про розбудову інфраструктури, необхідної населеному пункту, щоб покращити життєздатність місцевої економіки. Громадське суспільство також відіграватиме свою роль. Групи громадського суспільства забезпечують механізм, який допомагає 
доносити ідеї та умови до уряду. Вони сприяють підвищенню підзвітності, гарантуючи, що місцевими потребами та проблемами не нехтують, та співпрацюючи 3 урядами для пошуку рішень. Таким чином, для переходу на модель сталого розвитку саме держава повинна проявити ініціативу, і зрештою ухвалити правильні рішення.

\section{Література:}

1. Шаповалова О. В. Адаптація господарського законодавства до вимог СС щодо сталого розвитку. Актуальні проблеми права: теорія і практика. 2016. №32. С. 25-40

2. Наїр Чандран. Держава сталого розвитку. Майбутнє урядування, економіки та суспільства. К.: Наш Формат, 2020. 288c.

3. Рейтинг устойчивого развития украинского бизнеса 2021: КорреспонденT.net. URL: https://esg-rating-2021.korrespondent.net/ 